\title{
Corporate Governance Impressions of Third Party Funds and Financial Performance
}

\author{
Deni Juliasari \\ Department of Accounting, STIE Widya Gama Lumajang \\ Email: denijuliasari.js@gmail.com
}

https://doi.org/10.30741/wiga.v10i1.515

\begin{tabular}{ll} 
A R T I C L E I N F O & A B S T R A C T \\
\cline { 2 - 2 } $\begin{array}{l}\text { Date of entry: } \\
\text { 20 January 2020 }\end{array}$ & $\begin{array}{l}\text { Financial performance is an important thing that must be achieved by every } \\
\text { company because it is reflection of company's ability to manage and } \\
\text { Revision Date: }\end{array}$ \\
allocate the resources. This performance has a relationship with GCG and \\
DPK. Then this study want to analyze the relationship of GCG and DPK to \\
this performance not only on direct reffect but also on indirect too. This \\
23 March 2020 & $\begin{array}{l}\text { study uses a quantitative approach with path analysis as testing model. The } \\
\text { population for this study ia 41 banking companies listed on the Indonesia }\end{array}$ \\
& Stock Exchange 2011-2015,. The sampling technique used purposive \\
& sampling technique, then obtained 28 companies that met the criteria, so the \\
& total sample was 140 observations (firm-years). The results showed that \\
GCG does not affect company performance but DPK has a positive effect to \\
the performance. Other than that GCG has a positive effect for financial \\
performance with DPK as an intervening variable.
\end{tabular}

Keywords: GCG, DPK and Financial Performance

\section{INTRODUCTION}

Financial performance is one of the benchmarks in assessing a company, and good financial conditions tend to attract the attention of investors, about performance, financial statements often used as a basis for assessing company performance (Donald and Weygant, 2010). Public trust can be seen from the bank's Third Party Fund (DPK) because if unfortunate things are happening to the bank, customers will be able to get out of the bank quickly. The application of GCG principles also felt to be very important in the banking industry. GCG is closely related to making people believe that managers will benefit them, as well as believing that managers will not embezzle or invest in unprofitable projects related to funds that have been invested by investors to improve company performance through DPK.

Mahmood and Zaheer (2011) conducted a study on the impact of corporate governance fo bank financial performance in Pakistan, and it is evident that the implementation of GCG has a direct role in bank performance. Therefore, it recommended to bank management that the implementation of GCG be effectively socialized and internalized to all stakeholders, so that synergy in governance relationships among all GCG organs is achieved (Tobing, 2013). But there are also research results which state otherwise, Permatasari and Retno (2014), Mustofa (2014) state that GCG does not affect company performance, Fauziyah (2013) concludes that GCG does not affect ROA. Likely due to the low awareness of banks in implementing GCG. The company's 
management is not yet interested in the long-term benefits of implementing GCG. They apply not because of needs, but rather because of compliance with existing rules.

GCG implementation cannot be direct or short term. But it takes time and information about implementing GCG in the long run so that it can affect financial performance. The results of Sugiyanto's research (2011) also stated that improving financial performance cannot be done only through the application of GCG. Researchers assume that even though much effort made to develop and improve corporate governance in Indonesia, there is still much that needs to improve in general for companies whose information can be accessed openly. These two things are the background of the need for corporate governance, especially issuers and public companies in Indonesia. The expectation of researchers if the governance of listed companies and public companies is good, then it can spur other companies to improve their governance so that they can improve the performance of listed companies and public companies. The bank uses various strategies so that the public wants to invest its funds in the form of deposits.

The banking sector must give a variety of impressions and trust so that the public wants to invest their funds as a form of positive community response to the bank. Fluctuations in public trust can be seen from how the community responded. Community response means a response or response from the community. The response is a psychological term used to name reactions to stimuli received by the five senses (Poerwadarminta, 1987: 1012). What supports and underlies the size of a response is attitude, perception and participation. A person's attitude precedes the response to the process because the attitude is a tendency or willingness to behave when faced with a certain stimulus. The response is a positive and negative reaction given by the community (Poerwadarminta, 1987: 1012). Public response is proxied through funds from the wider community, also known as Third Party Funds (DPK). DPK is funds that come from deposits from the wider community, in various forms. Deposits according to RI Law No. 7 of 1992 are funds entrusted by the public to banks based on fund storage agreements in the form of demand deposits, deposits, savings and or other forms equivalent to that (www.bi.go.id).

Sudiyatno (2010) shows that DPK has a positive effect on Return On Assets (ROA), in line with research conducted by Kesowo et al., (2002). Irianti (2011) and Sudiyatno (2010) also show the results that DPK has a positive and significant effect on ROA. This shows the greater DPK, the higher ROA. While Lukitasari and Andi's (2015) research shows different results, DPK does not affect ROA due to the lack of effectiveness of the banking's role in collecting funds that not balanced with lending to the public. Sukma's research (2013) also found that DPK did not have a significant effect on ROA. The application of GCG by banks is also no less important in carrying out its operational activities during business competition. Public trust in the results of the implementation of GCG will lead to a response to the banking institution, a positive response to the implementation of good GCG makes the bank a trusted, healthy and efficient customer choice. It is strengthening the perception that the public trusts the bank's performance so that it creates a positive response from the public to save their funds to be managed by the bank.

Based on the relationship between GCG, and TPF, this study established TPF as an intervening variable that mediates the relationship between GCG and financial performance. GCG, public response, and financial performance are interesting to learn about its implementation as well as information communicated to the public by the company. Conflicting research results provide a reason for researchers to investigate more about the effect of GCG and DPK on financial performance. This research focuses on banking companies because banking companies have slightly different business activities compared to other sector companies. With the principle of GCG, namely, openness, where banks must disclose information not only of a financial nature but the principle of openness adopted by banks does not reduce the obligation to fulfil bank secrecy provisions. The performance evaluation of an entity today is not only measured from the financial aspect, but financial responsibility must also, of course, complemented by non-financial performance such as the application of GCG. The motivation underlying this study is that there are 
not many empirical research results about the influence of GCG and public response to financial performance in banking companies. Previous studies only partially tested each variable. Previous research examines the direct effect of GCG and public response on company performance, while this research integrates the variables that have investigated into a path analysis. Test the direct influence of GCG, and community response to company performance, and test the indirect effect of GCG on company performance through community response.

Jensen and Meckling (1976) state that an agency relationship is a contract between a manager and an investor. Conflicts of interest can occur because manager do not always act in the interests of the principal. Banks, as intermediary institutions, have a very large risk because the inability to maintain the image will greatly affect the public response. Prasinta (2012) explains that GCG is closely related to how to make people confident that managers will benefit them in every condition of companies. Zarkasyi (2008) theoretically, the application of GCG can increase public response to channelling funds or financing in banks. Without the effective implementation of GCG, it will be difficult for banks to strengthen their position, expand their networks, and show their performance more effectively. Therefore, the banking sector must provide a variety of impressions and beliefs so that people want to invest their funds as a form of good response from the public towards banks. Based on this all study here, then Hypothesis $1\left(\mathrm{H}_{1}\right)$ : GCG affects the response of the community.

GCG is a management mechanism based on agency theory. The application of GCG expected to provide trust in agents in managing principal wealth and principals become more confident that agents will not commit fraud. The principles of GCG also function to control the behaviour of company managers so that they not only benefit themselves but also benefit company owners. The interest of the owner of the fund is to obtain an adequate return on the funds invested (Gunarsih, 2007). The application of GCG principles also felt to be very important in the banking industry. Banks as the heart and driving force of a country's economy must apply GCG principles. The implementation of GCG by applicable regulations will benefit the creation of a better decisionmaking process, improve company efficiency, and further improve services, facilitate the obtaining of cheaper financing funds and because of the trust factor that will ultimately improve company performance (FCGI, 2001a). Then Hypothesis $2\left(\mathrm{H}_{2}\right)$ : GCG affects the company's performance.

Response or response can be interpreted generally as the result or impression obtained (left) from observations about the subject, event or relationships obtained by summarizing information and interpreting messages (Rahmat, 1999: 51). Based on signalling theory, the amount of CSR costs disclosed by the company in the annual report provides information to the public that the company is better than other companies. The GCG system will protect the people so that they believe they will get their investment back naturally and with high value. A good company performance begins with the trust of investors in a company that the funds they invest in safe conditions and expected to provide a good return. Evaluating investment decisions and assessing whether or not a company is healthy, is usually assessed through the financial performance of the company concerned. The bank must give various impressions and trust so that the public wants to invest their funds as a form of positive public response to the bank. Then Hypothesis 3 of this study is $\left(\mathrm{H}_{3}\right)$ : Public response influences the company's performance.

\section{RESEARCH METHODS}

The population in this study are banking companies listed on the Indonesia Stock Exchange in the 2011-2015. The method of determining the sample size used is purposive sampling, where sampling based on criteria 1. Companies in the bank sub-sector listed on the Indonesia Stock Exchange in the period 2011 - 2015. 2. Companies that not delisted in the 2011-2015 period. 3. Which has a complete data of research variables (composite value of the results of the self- 
assessment of GCG implementation of banks, DPK and ROA). so the number of observations is 140 (firm-years). This sample were analyzed using descriptive statistics and classic assumption tests with path analysis. The effect of mediation shown by the coefficient multiplication can be known its significance by being tested using the Sobel Tes (Ghozali, 2013

The quality of GCG implementation can be known through the composite self-assessment value in the GCG banking report or through the company's annual report. The results of the Bank's GCG self-assessment, setting a composite rating classification, are as follows:

Table 1. Classification of Composite Ratings

\begin{tabular}{|c|c|}
\hline Composite Value (NK) & Composite Value (NK) Composite \\
\hline Composite Predicate & Predicate \\
\hline NK $<1,5$ & Very good \\
\hline $1,5<\mathrm{NK}>2,5$ & Good \\
\hline $2,5<N K>3,5$ & Pretty good \\
\hline $3,5<\mathrm{NK}>4,5$ & Not good \\
\hline $4,5<\mathrm{NK}>5$ & Not good \\
\hline
\end{tabular}

Sources: (IBI and BARa, 2016: 136)

GCG factor rankings are categorized in 5 ranks namely rank 1, rank 2, rank 3, rank 4, and rank 5. The smaller GCG factor ranking reflects better GCG implementation, and for banks that obtain GCG rating 3, 4 or 5 must submit an action plan (Indonesian Banking Booklet, 2017).

Kasmir (2012: 59) one of the liabilities of banking companies that can increase profitability is the number of third party funds obtained by the company. Third-party funds (DPK) can be defined as funds sourced from the wider community and is the most important source of funds for a bank's operational activities. DPK can also be used as a measure of the success of a bank if the bank can finance its operations based on third party funding sources. Kasmir (2012: 64) also states that from some sources of funds, third party funds have the greatest contribution, so that the ability of banks to extend credit influenced by deposits that have been collected by banks. Based on this statement, it can conclude that the more DPK a bank gets, the funds that will be distributed back to the community in the form of credit will also increase. The greater the amount of credit that channelled back to the community, the profit the bank will get even greater. When company profits are higher, bank profitability will increase in terms of asset use by utilizing Dendawijaya's corporate liabilities (2009: 49). In the annual report, the banking company states that usually increase the number of third party funds as a form of positive response and trust from the public. Zarkasyi (2008: 112) theoretically, the application of GCG can increase the public's response to channelling funds, namely or financing in banks. DPK $=$ Ln Total DPK.

Company performance is what has been achieved by the company with existing standards or plans in the company. Wibowo et al. (2106) stated that the financial performance (performing measurement) of a company could see from the profit or profitability. Profit is a measure of financial performance. Financial performance in this study is proxied by ROA. ROA measurement tool was chosen in this study because ROA can calculate how the ability of bank management in obtaining profitability by utilizing the overall assets of the company and Return on Assets (ROA) is considered able to represent other parameters. Return On Equity (ROE) only illustrates the ability of banks to earn profits by utilizing invested capital, and Net Interest Margin (NIM) illustrates earnings only according to productive assets (IBI and BARa, 2016: 139) ROA = Profit before tax / average total assets. 


\section{RESULTS AND DISCUSSION}

SPSS display output shows the smallest (minimum) GCG observation data is (1) Bank Central Asia Tbk., (2) Bank Nusantara Parahyangan Tbk., (3) Bank Internasional Indonesia Tbk., (4) Bank Permata Tbk., (5) Bank OCBC NISP Tbk. in 2011, (6) Bank Bukopin Tbk., (7) Bank Nusantara Parahyangan Tbk., (8) Bank CIMB Niaga Tbk., (9) Bank Permata Tbk. in 2012, (10) Bank Central Asia Tbk., (11) Bank Bukopin Tbk., (12) Bank QNB Kesawan Tbk., (13) Bank CIMB Niaga Tbk., (14) Bank Internasional Indonesia Tbk., (15) ) Bank Artha Graha Internasional Tbk. in 2013, (16) Bank Central Asia Tbk., (17) Bank Bukopin Tbk., (18) Bank CIMB Niaga Tbk. in 2014, (19) Bank Central Asia Tbk., (20) Bank Bukopin Tbk., (21) Bank Negara Indonesia (Persero) Tbk., (22) Bank CIMB Niaga Tbk., (23) Bank Maybank Indonesia Tbk. in 2015. And the largest bank GCG is (1) State Savings Bank (Persero) Tbk, (2) Bank JTrust Indonesia Tbk. in 2013, and (3) Bank JTrust Indonesia Tbk. in 2014. The average GCG based on 140 observational data was 1.8614 with a standard deviation of 0.64291 . The standard deviation is smaller than the average value. This condition shows that good GCG data is distributed to the sample banking companies.

The smallest (minimum) community response is 22.70 , which is the community response owned by Bank Nusantara Parahyangan Tbk. in 2015 and the largest public response (maximum) was 34.14 owned by Bank Rakyat Indonesia (Persero) Tbk. in 2011. The average community response based on 140 observational data was 30.5860 with a standard deviation of 2.30735 . The standard deviation is smaller than the average value. This condition shows that good public response data spread in the sample banking companies. The smallest (minimum) company performance is 10.28 which is the company's performance owned by Bank Sinarmas Tbk. in 2015, and the largest company performance (maximum) was 77.39 owned by Bank Pundi Indonesia Tbk. in 2015. The average company performance based on 140 observational data was 22.9531 with a standard deviation of 10.12695. The standard deviation is smaller than the average value. This condition shows that the spread of good corporate performance data in the sample banking companies.

The classic assumption test is performed to determine deviations in the research data so that the path model is BLUE (Best Linear Unlocked Estimated). The classic assumptions used in this study are multicollinearity, autocorrelation, heteroscedasticity and normality tests. It can be seen that the tolerance value of the GCG variable is 0.954 greater than 0.10 , while the VIF value of the GCG variable is 1.048 less than 10.00. The tolerance value of the GCG and DPK variables is 0.929 and 0.934 greater than 0.10 , while the VIF variable values, GCG and DPK are 1.076, 1.071 less than 10.00. So it can be concluded that there is no multicollinearity between independent variables in the regression model. The number of independent variables is one variable so that the upper bound value $(\mathrm{du})$ is 1.7382 , and the lower bound value $(\mathrm{dl})$ is 1.17095 . Model 2, the number of independent variables is two variables so that the upper bound value (du) is obtained 1.7529, and the lower bound value ( $\mathrm{dl}$ ) is 1.6950 . DW value 2.002 is greater than the upper limit (du) 1.7382 and less than $4-1.7382=2.2618(4-\mathrm{du})$, it can be concluded that there is no autocorrelation in model 1. While in model 2 the DW value is 1,790 greater than the upper limit (du) 1.7529 and less than $4-1.7529=2.2471(4-\mathrm{du})$, it can be concluded that there is no autocorrelation in model 2 .

Regression model 1 with the GCG independent variable on the residual absolute dependent variable did not show any symptoms of heteroscedasticity with a significance value of each greater than 0.05. Means it can be concluded that the regression model 1 does not contain any heteroscedasticity. Regression model 2 with GCG independent variables and public response to the residual absolute dependent variable did not show any symptoms of heteroscedasticity with each significance value greater than 0.05. Means it can be concluded that the regression model 2 does not contain heteroscedasticity. Residual normality indicated by the unstandardized residual variable has a significance value greater than 0.05 , which is significant at 0.709 , so it can be concluded that the residual data is normally distributed. 
The form of structural equation is as follows: Community Response $=19,393+-0,730 \mathrm{GCG}+\mathrm{e} 1$ (Model 1). Company Performance $=-63,818+2,662 \mathrm{GCG}+2,491$ community response $+\mathrm{e} 2$ (Model 2). Based on the two-equation models above, things can be interpreted as follows: Model 1: Coefficient of GCG Variables. Based on the results of the hypothesis test (t-test), the GCG variable showed an unstandardized beta value of -0.730 . Unstandardized beta coefficient value 0.730 is the value of path or path p1. Model 2: GCG Variable Coefficient. Based on the results of the hypothesis test (t-test), GCG variables showed an unstandardized beta value of 2.662. The unstandardized beta coefficient value 2.662 is the value of the path or path p4-variable Coefficient of Community Response. Based on the results of the hypothesis test (t-test), the community response variable showed an unstandardized beta value of 2.491 . The unstandardized beta coefficient value 2.491 is the value of path or path $\mathrm{p} 3$. The magnitude of e $1=\sqrt{ }(1-0,327)=$ 0,673 and the magnitude of e $2=\sqrt{ }(1-0,168)=0.832$.

The path analysis results show that GCG can directly influence the response of the community, the magnitude of the direct effect is -0.730 . Community response can directly influence company performance, the amount of direct influence is 2.491. The indirect effect can be known by calculating the indirect coefficient multiplication, namely: The indirect effect of GCG on company performance through public response (p2 x p3 $=-0,730 \times 2,491=-1,818$ or the total effect of GCG on company performance $=2,662+(-1,818)=0.844$. The effect of mediation shown by the coefficient multiplication can be known for its significance by being tested using the Sobel Test (Ghozali, 2013) as follows: Calculate the standard error of the coefficient of indirect effect Indirect influence of GCG on company performance through public response $(\mathrm{Sp} 4 \mathrm{p} 5) .=\sqrt{\mathrm{p}} 32 \mathrm{Sp} 22+\mathrm{p} 22$ Sp32 + Sp22 Sp32, Sp2p3 $=\sqrt{ }(2,491) 2(0,192) 2+(-0,730) 2(0,780) 2+(0,192) 2(0,780) 2$, $\mathrm{Sp} 2 \mathrm{p} 3=\sqrt{0,229}+0,324+0.02222, \mathrm{Sp} 2 \mathrm{p} 3=\sqrt{ } 0.575=0.759$.

Calculate the value of $\mathrm{t}$ statistics or $\mathrm{t}$ calculate the effect of mediation with the following formula, Model $1, \mathrm{t}=\mathrm{p} 1 \mathrm{p} 3 / \mathrm{Sp} 1 \mathrm{p} 3=0.692 / 0.245=2.82$. Because the value of $\mathrm{t}$ arithmetic $=2.82$ is greater than the value of $t$ table with a significance level of 0.05 which is 1.98 , it can be concluded that the mediation coefficient is 0.692 , which means that there is a mediating effect. Model $2, \mathrm{t}=$ $\mathrm{p} 2 \mathrm{p} 3 / \mathrm{Sp} 2 \mathrm{p} 3=(-1,818) / 0.759=-2.39$. Because the value of $\mathrm{t}$ arithmetic $=-2.39$ is greater than the value of t table with a significance level of 0.05 which is 1.98 , it can be concluded that the mediation coefficient is -1.818 , which means that there is a mediating effect.

Based on the results of hypothesis testing, which shows that GCG has a negative effect on community responses with a significance value of 0,000 . The smaller ranking of GCG factors reflects better GCG implementation. With the effective implementation of GCG, banks can strengthen their positions, expand their networks, and show their performance more effectively. Proven implementation of GCG by banking companies is able to increase public confidence so that people will use more services that have been provided by banks. It also supports agency theory based on agency problems that arise when managing a company is separate from its owner. The existence of these two participants (principal and agent) raises issues regarding the mechanism that must be formed to align the different interests between the two. Researchers assume GCG spurs the formation of professional, transparent, clean and sustainable management patterns. Good GCG implementation through the composite value of GCG self-assessment results in the company's annual report is also able to maintain the image (quality) of the bank as an intermediary institution. This is proven by the good response from the community with the increase in thirdparty funds. Banks are able to provide trust so that the public wants to invest their funds as a form of good response from the community towards the bank. This research supports Prasinta's research (2012) GCG is closely related to how to make people believe that managers will provide benefits for them, confident that managers will not embezzle or investing in projects that are not profitable related to the capital that has been invested. Because banking companies tend to rely on capital from external parties to finance their operational activities, companies need to convince external funders that their investments are used appropriately and efficiently (Nuswandari, 2009). 
Based on the results of hypothesis testing, which shows that GCG has no effect on company performance with a significance value of 0.152 . Based on agency theory, GCG principles function to control corporate management behaviour so that it not only benefits itself but also benefits the company owner. But this research contradicts that theory. The precautionary principle applied by management in channelling credit causes a lack of channelling of funds in the form of a credit to the public. With the decline in lending, it also decreased profits generated by banks. The results of this study are in line with the research by Permatasari and Novitasary (2014), which states that the implementation of GCG has no effect on the performance of banks in Indonesia. Good GCG implementation in banks does not guarantee to improve the performance of the bank concerned. Mustofa and Haryanto (2014) revealed that GCG criteria should not only be calculated through self-assessment values; there are still many other factors that influence the value of GCG composite banking.

Based on the results of hypothesis testing, which shows that public response has a positive effect on company performance with a significance value of 0.002 . Supported by response theory can be interpreted generally as a result or impression obtained from observations about the subject, events or relationships obtained by summarizing information and interpreting messages (Rahmat, 1999: 51). A good company performance begins with the trust of the public towards a company that the funds they invest in are safe and are expected to provide good returns. Because as a service institution, banks are very vulnerable to issues that can cause a decline in public confidence. Banks provide a good image and trust so that the public wants to invest their funds in the form of third party funds as a form of positive public response to banks. Increasing the number of DPK then channelled into credit. Loans disbursed by banks will get a rate of return in the form of interest. Furthermore, the size of the interest will greatly affect the company's financial performance. Optimizing positive community responses through DPK is very important in improving company performance. Among them, when given information on the amount of CSR and GCG costs of the company, it was proven that the public responded positively to the increasing number of DPK in the company. This study supports research conducted by Sudiyatno (2010) and Kesowo et al., (2002), showing that DPK has a positive effect on Return on Assets (ROA).

Based on the results of the hypothesis test conducted, it shows that GCG has an effect on company performance through public response. Banks as the heart and driving force of a country's economy must apply GCG principles. According to Bismar (2007), the importance of the role and function of the bank is known from several aspects of the business that are considered the most attractive because the business was started and funded by the public. To improve financial performance, companies need to develop guidelines for good and structured management. A good financial performance will also result in the formulation of a good corporate strategy planning, which ultimately results in a good work program and impacts on the profits or profits of the company. This can be achieved if there are cooperation and good governance of all components of the company. The theory that supports the research is agency theory based on agency problems that arise when managing a company apart from ownership. The company is a mechanism that provides opportunities for various participants to contribute in the form of capital, expertise and labour in order to maximize long-term benefits. The existence of these two participants (principal and agent) raises issues regarding the mechanism that must be formed to align the different interests between the two.

The consistent application of GCG principles is proven to be able to improve the quality of financial statements and can also be an obstacle to performance engineering activities that result in financial statements not reflecting the fundamental value of the company (Sochib, 2015). The existence of a company is also strongly influenced by the support given by stakeholders to the company. By knowing what stakeholders want, managers can formulate a flexible company strategy. This strategy accommodates not only all stakeholder interests but also the company's ultimate goal (Listiyanti, 2011). In banking, performance measurement uses a composite index that complex measures how the bank's performance is seen from the financial and non-financial 
sectors, such as measuring profitability, ability to manage risk, ability to maintain capital, quality of management/governance, and so on. These matters are contained in regulations issued by Bank Indonesia (2007) and OJK (2014). The composite value of the report on GCG self-assessment results of bank companies is one form of GCG implementation in the company.

The researcher believes that the purpose of the GCG self-assessment report is to provide additional information about the company's activities as well as a means to signal stakeholders about other activities of the company, or a sign that the company not only provides information based on regulatory requirements but provides more information for the stakeholder's stakeholders. This signal is expected to be received positively by the market so that it can affect the company's financial performance because every activity carried out by the company will have an impact on stakeholders. The activity is the concern and interest of the stakeholders, especially investors and potential investors of the company. A good signal from the report of the GCG self-assessment results will further lead to a response. The response is a positive and negative reaction given by the community (Poewadarminta, 1987: 1012). In this case, a good response can be from the public on the implementation of corporate GCG shown by increasing DPK in banking companies. ThirdParty Funds can also be used as a measure of the success of a bank if the bank can finance its operations based on Third Party Fund sources. Kasmir (2012: 59) one of the liabilities of a banking company that can increase profitability is the amount of DPK obtained by a company.

It can be concluded that the implementation of good GCG does not necessarily have an impact on the company's financial performance. However, the composite value of the results of the GCG self-assessment provides a good opportunity for the company to achieve various benefits, including investor confidence in the company. The public wants to leave their funds at the bank if there is an element of trust. The community believes that the money will not be misused by the bank, the money will be well managed, the bank will not go bankrupt, and at the time that has been promised the deposits can be withdrawn from the bank. Empirically proven, the better composite index of the results of the GCG self-assessment of the bank will cause a positive response to the community so that people want to invest their funds in the bank so that the increasing number of DPK can increase the number of company DPK. The amount of DPK as a form of positive response from the community will be channelled into credit. Loans disbursed by banks will get a rate of return in the form of interest. Furthermore, the size of the interest will greatly affect the size of the profitability.

The main goal of each company is to obtain maximum profit where the increase in profitability shows that the financial performance of a company has increased (Wibowo et al., 2016). The test results show the GCG mediation coefficient on company performance through community response has a value of $\mathrm{t}$ arithmetic $=-3,803$ is greater than the value of $\mathrm{t}$ table with a significance level of 0.05 that is equal to 1.98 , it can be concluded that the mediation coefficient is $-1,818$ significant, which means the community response is mediation variable.

\section{CONCLUSION}

This study aims to analyze the effect of GCG, on company performance with a public response as an intervening variable on banking companies listed on the Indonesia Stock Exchange in 20112015. This study analyzes the direct and indirect influence of GCG, on company performance with the public response. The research sample amounted to 140 observations. Based on the results of data analysis and discussion, the following conclusions can be drawn: The ranking of the smaller GCG factors reflects the better implementation of GCG, the better the GCG of the company, the better the community's response because the public wants to entrust their funds in the bank is based on the existence of an element of trust. The community believes that the money will not be misused by the bank, the money will be well managed, the bank will not go bankrupt, and at the time that has been promised the deposits can be withdrawn from the bank. Based on the 
information above, hypothesis 2, which states that GCG has a negative effect on community response, is proven to be correct or $\mathrm{H} 2$ is accepted.

Companies that have commitment and consistency in applying GCG principles to their company activities naturally foster public trust. The principles of GCG serve to control the behaviour of the company's management so that it not only benefits itself but also benefits the company owner. However, good GCG implementation does not necessarily have an impact on the company's financial performance. GCG is not only calculated through the value of self-assessment; there are still many other factors that influence the value of the GCG composite of the bank. Based on the information above, hypothesis 4, which states that GCG has no effect on company performance, is not proven true or $\mathrm{H} 4$ is rejected. A good company performance begins with the trust of the public towards a company that the funds they invest in are safe and are expected to provide good returns. Because as a service institution, banks are very vulnerable to issues that can cause a decline in public confidence. The bank provides a good image and trust so that the public wants to invest their funds as a form of positive public response to the bank so that it can improve company performance. Based on the information above, hypothesis 5, which states that public response has a positive effect on company performance, is proven true or H5 is accepted.

GCG has a positive effect on company performance with a public response as an intervening variable. Good GCG implementation does not necessarily have an impact on the company's financial performance. However, the composite value of the results of the GCG self-assessment provides a good opportunity for the company to achieve various benefits, including investor confidence in the company. The better the composite index of the results of the GCG selfassessment of the bank will cause a positive response to the community so that the public wants to put their funds in the bank as the increase in the number of DPK can increase the number of company DPK. The amount of DPK as a form of positive response from the community will be channelled into credit. Loans disbursed by banks will get a rate of return in the form of interest. Furthermore, the size of the interest will greatly affect the size of the profitability.

\section{REFERENCE}

Donald, K. E. dan Weygandt, J. J. (2010). Akuntansi Intermediate. Edisi kedua belas. Jilid 3. Jakarta: Erlangga.

Fauziyah, N. (2013). Pengaruh Risiko Usaha Dan Goodcorporate Governance (GCG) Terhadap Return On Asset (ROA) Pada Bank Pemerintah Indonesia. Thesis. Sekolah Tinggi Ilmu Ekonomi Perbanas Surabaya.

Ikatan Bankir Indonesia (IBI). (2016). Banker Association For Risk Management (Bara). Manajemen Kesehatan Bank Berbasis Resiko. Edisis Pertama. Jakarta: PT Gramedia Pustaka Utama.

Irianti, T. E. (2011). Pengaruh Rasio Kecukupan Modal, Likuiditas, Dan Total Dana Pihak Ketiga Terhadap Tingkat Profitabilitas Perusahaan Perbankan. Jurnal Ilmiah Inkoma, 24(1)

Lukitasari, Y. P. dan Andi, K. (2015). Analisis Pengaruh Dana Pihak Ketiga, BOPO, CAR, LDR Dan NPL Terhadap Kinerja Keuangan Pada Sektor Perbankan Yang Terdaftar Di Bursa Efek Indonesia. INFOKAM, 6(1)

Mahmood, I. dan Zaheer, A. (2011). Impact of Corporate Governance on Financial Performance of Banks in Pakistan. Interdisciplinary Journal of Contemporary Research in Business, 2(12)

Mustofa, M. I. dan Haryanto A. M. (2014). Jurnal Studi Manajemen \& Organisasi, 11 : $126-142$

Permatasari, I dan Retno, N. (2014). Pengaruh Implementasi Good Corporate Governance terhadap Permodalan dan Kinerja Perbankan di Indonesia: Manajemen Risiko Sebagai Variabel Intervening. JURNAL EKONOMI KUANTITATIF TERAPAN, 7(1) : 52-59. ISSN : $2301-8968$

Poerwadarminta. (1987). Kamus Umum Bahasa Indonesia. Jakarta: Balai Pustaka.

Prasinta, D. (2012). Pengaruh Good Corporate Governance Terhadap Kinerja Keuangan. Accounting Analysis Journal, 1(2). 
Sudiyatno, B. dan Jati, S. (2010). Analisis Pengaruh Dana Pihak Ketiga. BOPO, CAR dan LDR Terhadap Kinerja Keuangan Pada Sektor Perbankan Yang Go Publik di Bursa Efek Indonesia (BEI) Periode 2005-2008. Dinamika Keuangan dan Perbankan, 2(2): 125-137.

Sugiyanto, E. K. (2011). Peningkatan Return Saham dan Kinerja Keuangan Melalui Corporate Social Responsibility dan Good Gorporate Governance. Aset, 13(1): Hal. 47-56.

Sukma, Y. L. (2013). Pengaruh Dana Pihak Ketiga, Kecukupan Modal Dan Risiko Kredit Terhadap Profitabilitas (Perusahaan Perbankan yang Terdaftar di BEI). Artikel Ilmiah Universitas Negeri Padang.

Tobing, A. (2013). Pengaruh Penerapan Good Corporate Governance terhadap Tingkat Kesehatan dan Daya Saing di Perbankan Indonesia. Jurnal Manajemen Teknologi, 12(3). Print ISSN: 1412-1700; Online ISSN: 2089-7928. DOI: http://dx.doi.org/10.12695/jmt.2013.12.3.5.

Wibowo, Santoso., Yokhebed dan Lambok, T. (2016). Pengaruh CSR Disclosure Dan GCG Terhadap Nilai Perusahaan Dengan Kinerja Keuangan Sebagai Variabel Intervening Di Perusahaan Manufaktur Yang Terdaftar Di Bursa Efek Indonesia (2012-2014). Prosiding Seminar Nasional Multi Disiplin Ilmu \& Call For Papers UNISBANK.

Zarkasyi, M. W. (2008). Good Corporate Governance: Pada Badan Usaha Manufaktur, Perbankan dan Jasa Keuangan Lainnya. Bandung: Alfabeta

http://www.bi.go.id/id/perbankan/ikhtisar/lembaga/Contents/Default.aspx. Diakses 10 januari 2019 http://www.bi.go.id/id/publikasi/dpi/bank-devisa/Default.aspx. Diakses 10 Januari 2019.

http://www.bi.go.id/id/publikasi/dpi/bank-non-devisa/Default.aspx. Diakses 10 Januari 2019 http://www.bi.go.id/id/publikasi/jurnal-

ekonomi/Documents/82478c7a78924e3f87f76007a95b3b3eRenniwatySiringoringo6184.pd f. Diakses 20 Mei 2019

http://www.bi.go.id/id/tentang-bi/uu-bi/Documents/uu_bi_1099.pdf. Diakses 26 Januari 2019

http://www.ojk.go.id/id/kanal/perbankan/data-dan-statistik/booklet-perbankanindonesia/Documents/pages/booklet-perbankan-indonesia2017/BPI\%202017\%20Bahasa\%20Indonesia.pdf. Diakses pada 16 Desember 2019 